\title{
78.けい光ランプの点灯周波数及び照度の生体への影響
}

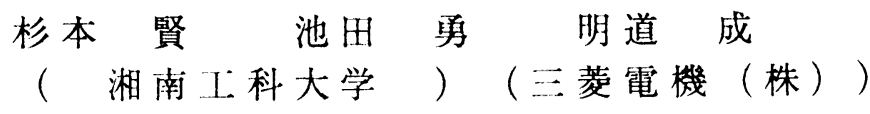

1.まえがき筆者らは、長年にわたり、種々の照明 環境とその生体へ及浭す影響について検討を重ねて来 ているが、今回は、けい光ランプの点灯周波数及び照 度の生体への影響について心拍・呼吸を指標として実 験研究を行った。あわせて、アンケート形式により心 理的影幚についても検討したので、以下に報告する。

2. 奏験方法 3 波長形F Lを光源として、表 1 に示す 照明条件下で、25

表 1 実条件

分間 $10 \mathrm{P}$ 活字で

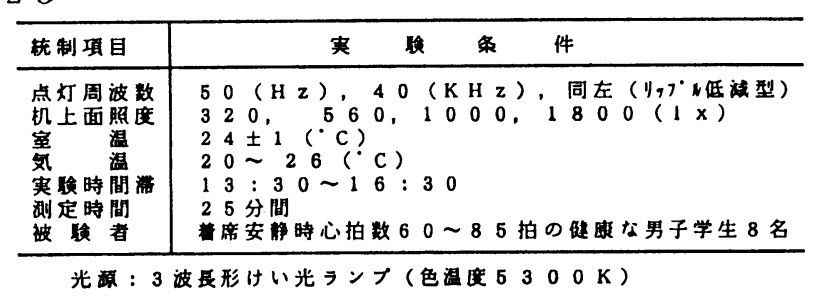
印刷された乱数 表より指定され た数字を抹消す る作業を被験者 に課し、その間

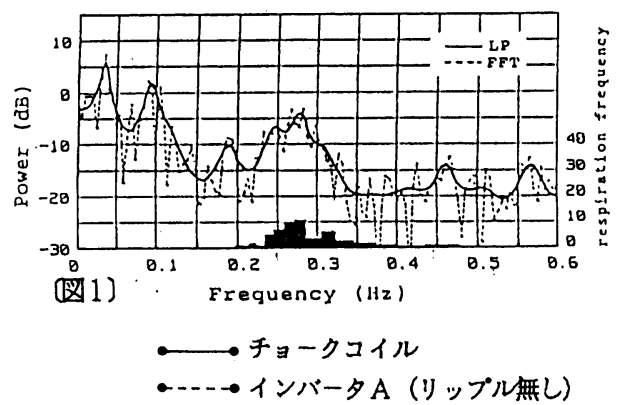
心電図の $\mathrm{R}-\mathrm{R}$ 間隔より導出された瞬時心拍数と呼吸曲

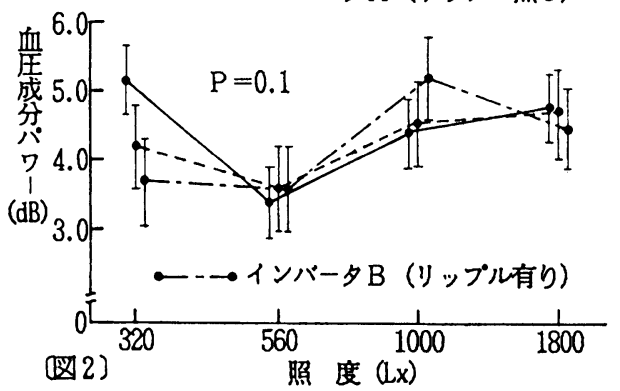
線を同時に連続計測した。

\section{3. 結果と考察}

連続計測された瞬時心拍数列を時系 列信号と見なして、AR 線形子測法によりパワースペク トルを求めると、図 1 が得られる。0.1 Hz 付近のパワ ピークは血圧性変動成分と言われ、交感神経の緊張度を分 反映して精神神経的な負荷又は刺激が增加する程顕著 に現われ、鰂荷刺激が過大になると抑制される。この 成分のパワーピーク值と照度との関係を図 2 に示す。い ずれの点灯装置でも560 Lxで最小となった。インバ. 夕Bの $1800 \mathrm{Lx}$ での減少は、抑制作用によるものと思 われる。図 3 に 25 分間の平均心拍数と照度との関係を 示す。チョ・クコイル、インバータ A とも560 L x で最 小を示し、インバータ Bの $320 \mathrm{Lx}$ を抑制作用と考える と、この場合も前記と同様になる。(チョークコイルの $1800 \mathrm{Lx}$ の隇少も抑制と考えられる)これらの結果か ら呼吸デ-夕も参照して求めた生理的負担の推定值（チ ヨークコイル・560 Lxの值を基準)を図4に示す。こ の図は、いずれの点灯装置でも560Lxで生理的顀担は 最小となり、点灯装置間での生理的負担の差は明確で ないことを示している。

図 5 にアンケート形式による心理評価の結果を示す。 これは、いずれの点灯装㯰でも、照度が高い程（イン バー夕Aについては1000Lxの場合に）心理的には好ま しく、生理的負担が最小となる照度と一致しないこと を示している。
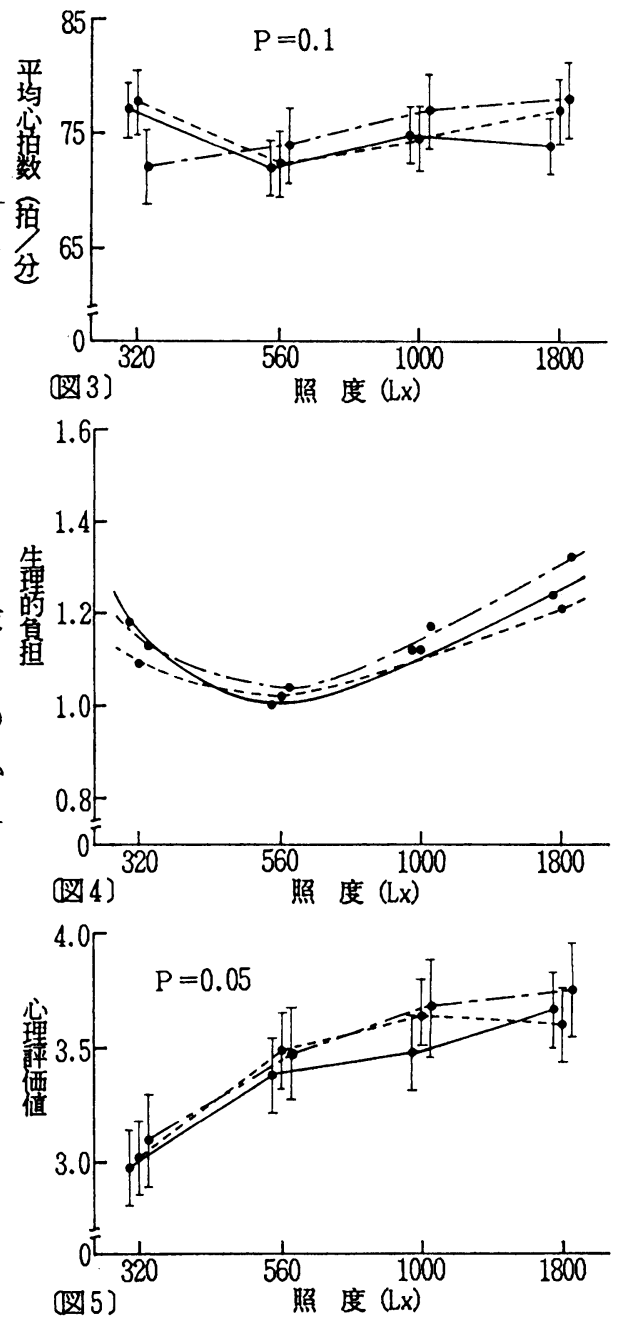

Effects of operating frequency and illuminance of FL on man. Suguru Sugimoto, Isamu Ikeda and Osamu Myodo 